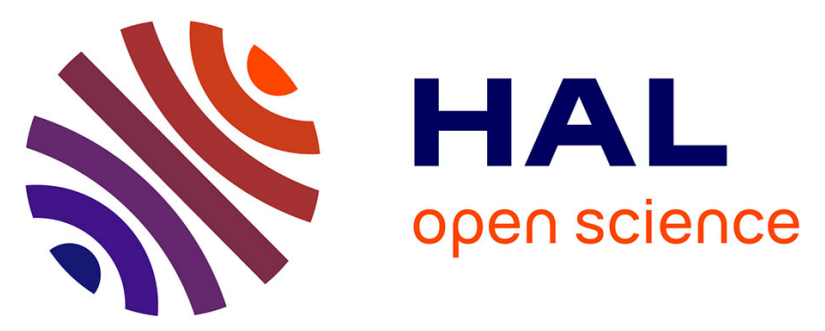

\title{
Fast and Highly Selective Continuous-Flow Catalytic Hydrogenation of a Cafestol-Kahweol Mixture Obtained from Green Coffee Beans
}

Fernanda Alves Lima, Marco A. M. Bezerra, Rodrigo Souza, Ivaldo Itabaiana, Tommy Haynes, Sophie Hermans, Robert Wojcieszak, Fábio Junior M. Novaes, Claudia Moraes Rezende

\section{To cite this version:}

Fernanda Alves Lima, Marco A. M. Bezerra, Rodrigo Souza, Ivaldo Itabaiana, Tommy Haynes, et al.. Fast and Highly Selective Continuous-Flow Catalytic Hydrogenation of a Cafestol-Kahweol Mixture Obtained from Green Coffee Beans. ACS Omega, 2020, 5 (40), pp.25712-25722. 10.1021/acsomega.0c01835 . hal-03024504

\section{HAL Id: hal-03024504 \\ https://hal.univ-lille.fr/hal-03024504}

Submitted on 25 Nov 2020

HAL is a multi-disciplinary open access archive for the deposit and dissemination of scientific research documents, whether they are published or not. The documents may come from teaching and research institutions in France or abroad, or from public or private research centers.
L'archive ouverte pluridisciplinaire HAL, est destinée au dépôt et à la diffusion de documents scientifiques de niveau recherche, publiés ou non, émanant des établissements d'enseignement et de recherche français ou étrangers, des laboratoires publics ou privés.

\section{(ㅇ)(1) $\$$}

Distributed under a Creative Commons Attribution - NonCommerciall 4.0 International 


\section{Fast and Highly Selective Continuous-Flow Catalytic Hydrogenation of a Cafestol-Kahweol Mixture Obtained from Green Coffee Beans}

Fernanda Alves Lima, Marco A. M. Bezerra, Rodrigo Souza, Ivaldo Itabaiana, Jr, Tommy Haynes, Sophie Hermans, Robert Wojcieszak, Fábio Junior M. Novaes, and Claudia Moraes Rezende*

Cite This: ACS Omega 2020, 5, 25712-25722

Read Online

ACCESS

Wll Metrics \& More

Article Recommendations

Supporting Information

ABSTRACT: This work investigates batch and continuous-flow heterogeneous catalytic hydrogenation of a mixture of cafestol and kahweol $(\mathrm{C} \& \mathrm{~K})$ to obtain pure cafestol. These diterpenes were extracted from green coffee beans, and hydrogenation was performed using wellestablished palladium catalysts $\left(\mathrm{Pd} / \mathrm{C}, \mathrm{Pd} / \mathrm{CaCO}_{3}, \mathrm{Pd} / \mathrm{BaSO}_{4}\right.$, and $\mathrm{Pd} /$ $\mathrm{Al}_{2} \mathrm{O}_{3}$ ) and a carbon black-supported Pd catalyst coated by a covalently tethered $\mathrm{SiO}_{2}$ shell with mesoporous texture (Pd/CB@ $\left.@ \mathrm{SiO}_{2}\right)$, all partially deactivated with quinoline. $\mathrm{Pd} / \mathrm{C} 10 \%$ poisoned with $1 \mathrm{wt} \%$ quinoline gave the best result for batch reaction, producing cafestol from kahweol with high selectivity (>99\%) after $10 \mathrm{~min}$. Excellent selectivity was also obtained with the catalyst $\mathrm{Pd} / \mathrm{CB} @ \mathrm{SiO}_{2}$ with only $1 \% \mathrm{Pd}$. In addition, $\mathrm{Pd} / \mathrm{C}$-quinoline adapted for continuous-flow experiments exhibited the best catalytic activity, also providing cafestol with excellent selectivity (>99\%) after $9.8 \mathrm{~s}$.

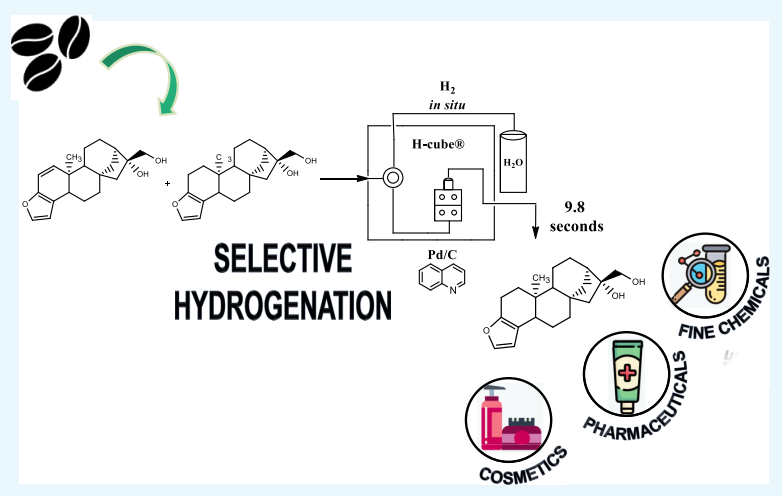

\section{INTRODUCTION}

The lipid fractions of green Robusta and Arabica coffees represent 7.7 to $18.0 \%$ of the total chemical composition of the beans. The pentacyclic diterpenes cafestol and kahweol (C\&K) are the main representatives of the unsaponifiable fraction of the coffee oil. ${ }^{1,2}$ In Coffea arabica, they may be present in free form (around $0.4 \% \mathrm{w} / \mathrm{w}$ of the lipid fraction) or esterified with different fatty acids (about 17\%) such as linoleic (44\%) and palmitic (30\%). ${ }^{3}$ Structurally, cafestol and kahweol are two entkaurene furane diterpenes that differ by one unsaturation between $\mathrm{C} 1$ and C2 (Figure 1). ${ }^{4}$

Cafestol has many biological activities reported such as antioxidant, ${ }^{5,6}$ anti-inflammatory, ${ }^{7,8}$ anticarcinogenic activities, ${ }^{9}$ and photoprotection capacity, ${ }^{10,11}$ which make this substance valuable to the pharmaceutical and cosmetic industries. The procedures described in the literature for the isolation of C\&K from green coffee beans involve the direct saponification of all acylated cafestol and kahweol compounds. ${ }^{12-14}$ Dias et al. ${ }^{3}$ performed the isolation of free $\mathrm{C} \& \mathrm{~K}$ from roasted coffee on an analytical scale using direct hot saponification (DHS) as a more efficient extraction method than Soxhlet and Bligh and Dyer.

Haworth et al. were the first to investigate the preparation of cafestol employing heterogeneous catalytic hydrogenation of a C\&K mixture. ${ }^{15}$ They observed that, after $30 \mathrm{~min}$, kahweol transformed into cafestol in the presence of $\mathrm{H}_{2}$ and $2 \%$ palladium on activated charcoal and ethanol as solvent. Nonetheless, the authors did not report the conversion of the reaction. Bertholet ${ }^{16}$ hydrogenated a C\&K mixture under batch conditions using palladium catalysts conditioned by lead acetate such as $\mathrm{Pd} / \mathrm{C}, \mathrm{Pd} / \mathrm{BaSO}_{4}, \mathrm{Pd} / \mathrm{Al}_{2} \mathrm{O}_{3}$, and Lindlar catalyst. The reaction with 5 wt $\% \mathrm{Pd} / \mathrm{C}$ and $\mathrm{Pd} / \mathrm{CaCO}_{3}$, poisoned with $\mathrm{Pb}$, transformed kahweol into cafestol (99\%) after $2 \mathrm{~h}$. Another experiment using $\mathrm{Pd} / \mathrm{Al}_{2} \mathrm{O}_{3}$ poisoned with $\mathrm{Pb}$ converted only $45 \%$ of kahweol and produced furan-ringopening products. A similar approach using $\mathrm{Pd} / \mathrm{BaSO}_{4}$ poisoned with $\mathrm{Pb}$ destroyed all the kahweol after $2 \mathrm{~h}$. Despite the good results with the first two catalysts, the high toxicity associated with $\mathrm{Pb}$ is a massive problem for the preparation of highly pure pharmaceuticals and fine chemicals. Thus, alternative additives were studied to find suitable replacements for lead acetate, preserving the high conversion and selectivity. Quinoline is as a reversible modifier used in heterogeneous hydrogenation reactions with palladium catalysts to enhance reaction selectivity by modifying the catalyst surface properties. ${ }^{17-19}$

Hydrogenation reactions of the $\mathrm{C} \& \mathrm{~K}$ mixture using batch strategies are usually effective. However, these processes have significant disadvantages, for instance, poor safety due to high

Received: June 22, 2020

Accepted: September 2, 2020

Published: September 28, 2020 


\section{Free form:}
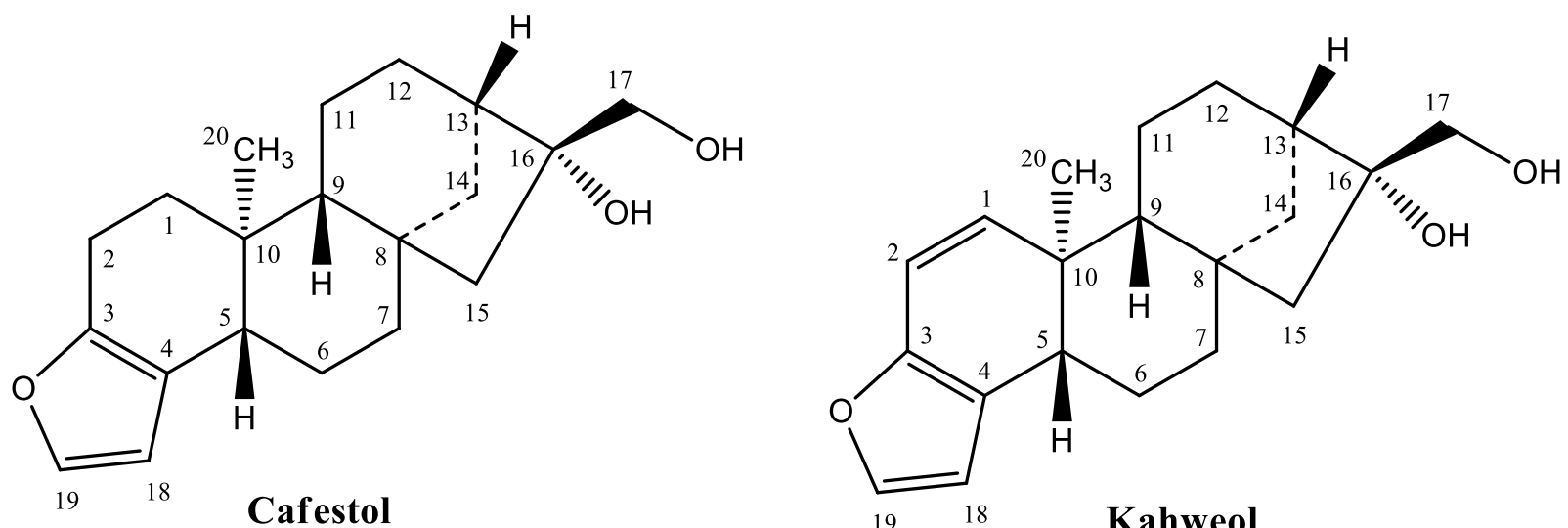

Esterified form:

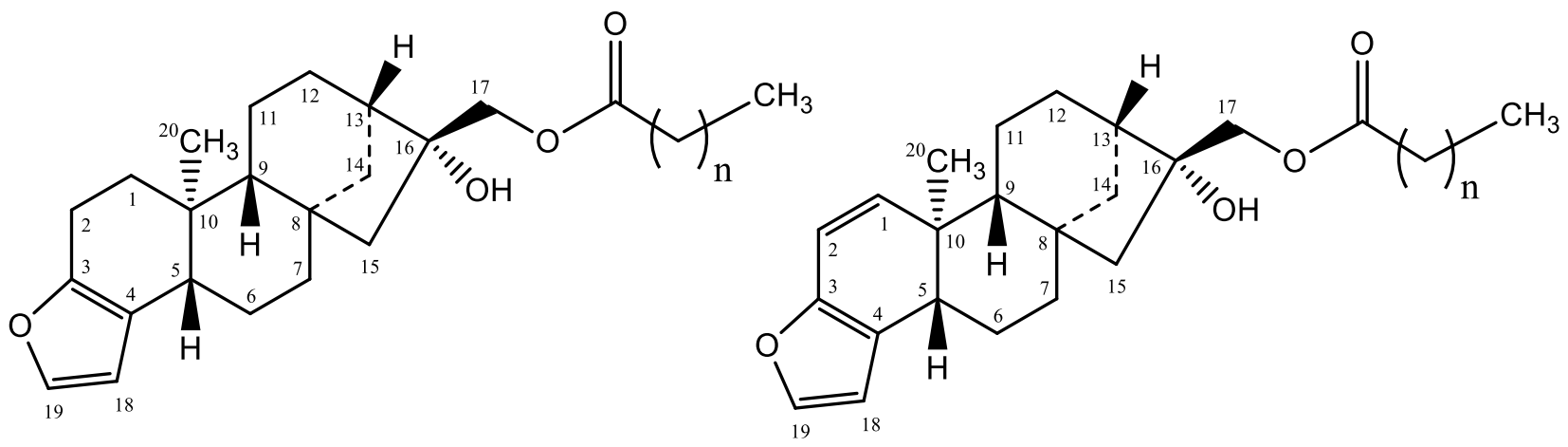

$\mathrm{n}=12,14,16,17,18,18: 1,18: 2,18: 3,20,21$ or 22.

Figure 1. Chemical structures of cafestol and kahweol in free and esterified form.

operating pressures of hydrogen, long reaction times ( 2 to 4 $\mathrm{h}$ ), and the additional filtration step to remove the catalyst. A high-pressure continuous-flow system offers solutions to these problems. First, process safety is ensured by the in situ production of hydrogen through the electrolysis of water. Second, in this system, a gas-liquid mixture passes through a cartridge containing the catalyst that can be recovered by washing it with an appropriate solvent, without an impairment of the catalytic activity and selectivity. Last, it allows the chemical transformation to happen in a short time and solvent and energy economy in a much smaller space. ${ }^{20}$

This work presents a fast and highly selective procedure for the hydrogenation of $\mathrm{C} \& \mathrm{~K}$ to produce pure cafestol applying a high-pressure continuous-flow technique with palladium catalysts partially deactivated with quinoline. The experiments were conducted in batch and continuous-flow conditions to compare the efficiency of the two systems.

\section{RESULTS AND DISCUSSION}

Batch Hydrogenation of the C\&K Mixture. The experiments under batch conditions were performed using 5 $\mathrm{mg}$ of different palladium catalysts partially deactivated with 1 wt $\%$ quinoline. Table 1 summarizes the results of the selective hydrogenation of the $\mathrm{C} 1-\mathrm{C} 2$ double bond on the kahweol skeleton. The chromatograms are shown in the Supporting Information (Figures S2-S6).

The batch hydrogenation with $10 \% \mathrm{Pd} / \mathrm{C}$ resulted in the best outcome, producing cafestol (>99\%) after $10 \mathrm{~min}$ with selectivity $>99 \%$ (Table 1 , entry 2 ). The increase of reaction time to 30 or $60 \mathrm{~min}$ did not affect the excellent conversion and selectivity (Table 1 , entries 3 and 4 ). The reactions using the $\mathrm{Pd} / \mathrm{C} 10 \%$ catalyst with 1 wt $\%$ quinoline did not produce dehydration products (DP), involving the loss of the C-16 tertiary hydroxyl group, and furan ring hydrogenation products (FRHP), proposed by Guerreiro et al. ${ }^{21}$ and Lam et al. ${ }^{22}$ (see Figures 2 and 3 ). 
Table 1. Hydrogenation of C\&K with Different Pd Catalysts Deactivated with 1 wt\% Quinoline ${ }^{a}$

\begin{tabular}{|c|c|c|c|c|}
\hline entry & catalyst & $\begin{array}{l}\text { time } \\
(\min )\end{array}$ & $\begin{array}{c}\text { conversion } \\
(\%)\end{array}$ & $\begin{array}{l}\text { cafestol selectivity } \\
(\%)^{b}\end{array}$ \\
\hline 1 & $\mathrm{Pd} / \mathrm{C} 10 \%$ & 5 & 97.0 & 97.0 \\
\hline 2 & $\mathrm{Pd} / \mathrm{C} 10 \%$ & 10 & 100 & $>99.0$ \\
\hline 3 & $\mathrm{Pd} / \mathrm{C} 10 \%$ & 30 & 100 & $>99.0$ \\
\hline 4 & $\mathrm{Pd} / \mathrm{C} 10 \%$ & 60 & 100 & $>99.0$ \\
\hline 5 & $\mathrm{Pd} / \mathrm{CaCO}_{3} 5 \%$ & 5 & 92.0 & 90.0 \\
\hline 6 & $\mathrm{Pd} / \mathrm{CaCO}_{3} 5 \%$ & 10 & 100 & 97.0 \\
\hline 7 & $\mathrm{Pd} / \mathrm{CaCO}_{3} 5 \%$ & 30 & 100 & 96.0 \\
\hline 8 & $\mathrm{Pd} / \mathrm{CaCO}_{3} 5 \%$ & 60 & 100 & 93.0 \\
\hline 9 & $\mathrm{Pd} / \mathrm{BaSO}_{4} 5 \%$ & 5 & 79.0 & 79.0 \\
\hline 10 & $\mathrm{Pd} / \mathrm{BaSO}_{4} 5 \%$ & 10 & 88.0 & 88.0 \\
\hline 11 & $\mathrm{Pd} / \mathrm{BaSO}_{4} 5 \%$ & 30 & 100 & 91.0 \\
\hline 12 & $\mathrm{Pd} / \mathrm{BaSO}_{4} 5 \%$ & 60 & 100 & 89.0 \\
\hline 13 & $\mathrm{Pd} / \mathrm{Al}_{2} \mathrm{O}_{3} 10 \%$ & 5 & 69.0 & 62.0 \\
\hline 14 & $\mathrm{Pd} / \mathrm{Al}_{2} \mathrm{O}_{3} \quad 10 \%$ & 10 & 81.0 & 73.0 \\
\hline 15 & $\mathrm{Pd} / \mathrm{Al}_{2} \mathrm{O}_{3} \quad 10 \%$ & 30 & 94.0 & 82.0 \\
\hline 16 & $\mathrm{Pd} / \mathrm{Al}_{2} \mathrm{O}_{3} \quad 10 \%$ & 60 & 100 & 90.0 \\
\hline 17 & Pd/CB@SiO, 1\% & 5 & 74.0 & 73.0 \\
\hline 18 & Pd/CB@SiO, 1\% & 10 & 82.0 & 81.0 \\
\hline 19 & Pd/CB@SiO, 1\% & 30 & 85.0 & 82.0 \\
\hline 20 & $\mathrm{Pd} / \mathrm{CB} @ \mathrm{SiO}_{2}$ 1\% & 60 & 94.0 & 91.0 \\
\hline
\end{tabular}

${ }^{a}$ Reaction conditions: $100 \mathrm{mg}$ of C\&K, $5 \mathrm{mg}$ of Pd catalyst with $1 \mathrm{wt}$ $\%$ quinoline, $100 \mathrm{~mL}$ of ethanol $95 \%, 30 \mathrm{psi} \mathrm{H}_{2}$. ${ }^{b}$ Selectivity values based on GC absolute area.

Other catalysts provided high conversions and selectivities like $\mathrm{Pd} / \mathrm{CaCO}_{3}, \mathrm{Pd} / \mathrm{BaSO}_{4}$, and $\mathrm{Pd} / \mathrm{Al}_{2} \mathrm{O}_{3}$ (entries 6, 11, and 16 , respectively). However, they also produced dehydration products (DP) and furan ring hydrogenation products (FRHP) in the range between 1 and $8 \% .^{22,23}$

Bertholet ${ }^{16}$ reported that these catalysts, when conditioned by lead acetate, converted kahweol to cafestol only when the support used is calcium carbonate or active carbon. Barium sulfate destroys kahweol, and aluminum oxide only converts a minor proportion of this molecule. In this work, we saw that changing the modifier to quinoline better controls the catalyst activity, and it was possible to apply all catalysts available just by controlling the reaction time.

The Pd/CB@SiO 2 catalyst, with 1 wt \% metal content determined by ICP analysis described by Haynes et al, ${ }^{24}$ also achieved high selectivity (91\%). However, it did not wholly consume kahweol after $60 \mathrm{~min}$ (Table 1, entry 20). The significant reduction of $\mathrm{Pd}$ content makes this process interesting despite the longer reaction time and the formation of by-products. The catalyst synthesized in this work is a carbon black-supported Pd catalyst coated by a covalently tethered $\mathrm{SiO}_{2}$ shell with mesoporous texture. ${ }^{25}$ The porous nature of the silica layer protected $\mathrm{Pd}$ from deleterious reaction actions, improved the accessibility of the underlying $\mathrm{Pd}$ nanoparticles in the hydrogenation reactions, and optimized the metal catalytic activity, thus avoiding the formation of collateral products.

Continuous-Flow Hydrogenation of the C\&K Mixture. The experiments were performed in a H-Cube Mini Plus continuous-flow hydrogenation reactor (ThalesNano) using 5 or $10 \% \mathrm{Pd} / \mathrm{C}(30 \times 4 \mathrm{~mm}, 113 \mathrm{mg})$ specific cartridges for the $\mathrm{H}$-cube Mini Plus (see Figure S7 in the Supporting Information). A C\&K solution $\left(1 \mathrm{mg} \mathrm{mL}^{-1}\right)$ with 1 wt \% quinoline was pumped into the system with different flow rates (Table 2). For comparison, all reactions in the continuous-flow system were conducted in the same parameters as the batch process $\left(25{ }^{\circ} \mathrm{C}\right.$ and $30 \mathrm{psi} \mathrm{H}_{2}$ pressure). The flow rates were chosen based on expected residence times (10,60, and $120 \mathrm{~s}$ ), taking into account the gas-liquid mixture flow and reactor volume.

The Pd/C 5\% catalyst with 1 wt \% quinoline at $2.3 \mathrm{~mL}$ $\min ^{-1}$ and residence time of $9.8 \mathrm{~s}$ (Table 2, entry 1 ) obtained the best selectivity (>99\%), resulting in pure cafestol with no side product formation (Figure 4).

The time the substrates were in contact with the catalyst cartridge directly influenced the selectivity. By raising the residence time to 56.5 and $113.1 \mathrm{~s}$, a considerable increase in the formation of multiple hydrogenation products happened, such as the loss of C-16 tertiary hydroxyl followed by hydrogenation of the double bonds of the furan ring (as suggested by ions $m / z 300$ and 302) and a product in which hydrogenation took place in one of the double bonds of the furan ring $(m / z 318)$ (Figure 5), as proposed in Figures 2 and $3^{21,22}$ (Table 2).

Unlike in the batch reaction, the catalyst Pd/C $10 \%$ did not show good selectivity results in continuous-flow reaction despite the excellent conversion (Table 2). Since the 5\% Pd/C catalyst had an excellent conversion of kahweol with quick reactions, we decided to investigate the impact of quinoline addition and the increase of $C \& \mathrm{~K}$ concentration in the selectivity of the C\&K mixture hydrogenation reaction.

Effect of Quinoline Addition on Reaction Selectivity of Continuous-Flow Hydrogenation of C\&K. To better understand the influence of quinoline on the selectivity of the $\mathrm{C} \& \mathrm{~K}$ hydrogenation reactions by continuous flow, they were carried out with and without quinoline (Table 3 ).

Quinoline was essential for reactivity control of the palladium catalyst in continuous-flow hydrogenation, with improvement on selectivity. In the reactions without quinoline, it was possible to observe a considerable amount of FRHP (17\%) after $9.8 \mathrm{~s}$. With $1 \mathrm{wt} \%$ quinoline, however, there was a total conversion of kahweol into cafestol (Table 3, entries 1 and 2; Figure 6).

The Pd/C 5\% catalyst, without quinoline and increased residence time $(56.5 \mathrm{~s})$, favored the formation of FRHP

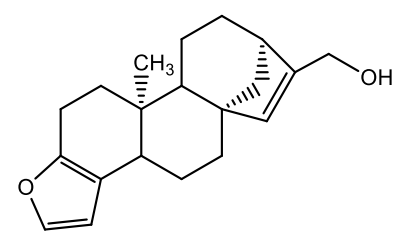

$m / z 298$

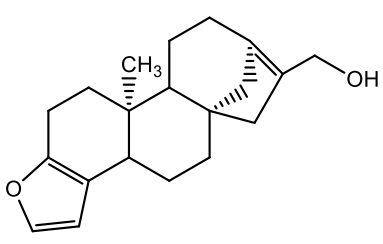

$m / z 298$<smiles>C[C@]12CCc3occc3C1CC[C@@]13C[C@@H](CC[C@@H]1C=O)C23</smiles>

$m / z 298$

Figure 2. Dehydration products from cafestol. 
<smiles></smiles>

$m / z 300$<smiles>C[C@]12CCC3=C(CCO3)C1CC[C@@]13CCC(C[C@@H]12)[C@H](CO)C3</smiles>

$m / z 300$<smiles>C[C@]12CCC3=C(CCO3)C1CC[C@]13C[C@H](CCC12)C3</smiles>

$m / z 300$<smiles>C[C@]12CCC3=C(CCO3)C1CC[C@@]13C[C@@H](CCC21)[C@@]3(O)CO</smiles>

$m / z 318$<smiles>C[C@]12CCC3OCCC3C1CC[C@@]13C[C@@H](CCC12)[C@@](O)(CO)C3</smiles>

$m / z 320$

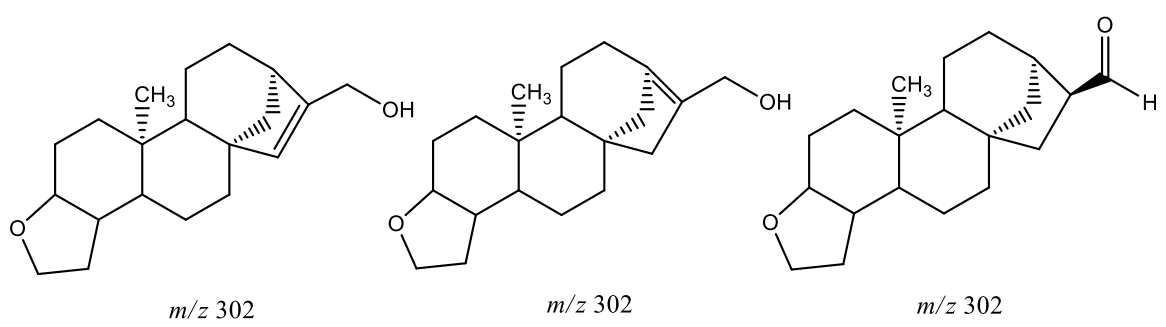

Figure 3. Furan ring hydrogenation products (FRHP).

Table 2. Continuous-Flow Hydrogenation of C\&K with Pd/ C and Quinoline ${ }^{a}$

$\begin{array}{cccccc}\text { entry } & \text { catalyst } & \begin{array}{c}\text { flow rate } \\ \left(\mathrm{mL} \mathrm{min}^{-1}\right)\end{array} & \begin{array}{c}\text { residence } \\ \text { time }(\mathrm{s})\end{array} & \begin{array}{c}\text { conversion } \\ (\%)\end{array} & \begin{array}{c}\text { cafestol } \\ \text { selectivity } \\ (\%)^{b}\end{array} \\ \mathbf{1} & \mathrm{Pd} / \mathrm{C} \mathrm{5 \%} & 2.3 & 9.8 & 100 & >99 \\ \mathbf{2} & \mathrm{Pd} / \mathrm{C} \mathrm{5 \%} & 0.4 & 56.5 & 100 & 61 \\ \mathbf{3} & \mathrm{Pd} / \mathrm{C} \mathrm{5 \%} & 0.2 & 113.1 & 100 & <1 \\ \mathbf{4} & \mathrm{Pd} / \mathrm{C} \mathrm{10 \%} & 2.3 & 9.8 & 100 & 33 \\ \mathbf{5} & \mathrm{Pd} / \mathrm{C} \mathrm{10 \%} & 0.4 & 56.5 & 100 & <1 \\ \mathbf{6} & \mathrm{Pd} / \mathrm{C} \mathrm{10 \%} & 0.2 & 113.1 & 100 & <1\end{array}$

${ }^{a}$ Reaction conditions: solution of $\mathrm{C} \& \mathrm{~K}$ in ethanol $\left(1 \mathrm{mg} \mathrm{mL}^{-1}\right)$ with $1.04 \mu \mathrm{L}$ of quinoline ( $1 \mathrm{wt} \%$ catalyst), $113 \mathrm{mg}$ of $\mathrm{Pd} / \mathrm{C}$ catalyst, 25 ${ }^{\circ} \mathrm{C}$, flow rates of $2.3,0.4$, and $0.2 \mathrm{~mL} \mathrm{~min}^{-1}$. ${ }^{b}$ Selectivity values based on GC absolute area.

products, primarily isomers of $m / z 302$. With quinoline, the same reaction had a selectivity of $61 \%$, and $39 \%$ of FRHP was observed (Table 3, entry 4). All kahweol was converted to FRHP when the residence time was $113 \mathrm{~s}$, with quinoline or not (Table 3, entries 5 and 6).

$\mathrm{Yu}^{26}$ reported that quinoline improves hydrogenation selectivity and suppresses adverse reactions by blocking the active sites of the catalyst, affecting its electronic properties and diluting its adsorption sites. In this study, we found that the use of quinoline was indispensable to achieve excellent conversion and selectivity results without the use of lead-poisoned catalysts, such as the traditional Lindlar catalyst.

To determine the time that $1 \mathrm{wt} \%$ quinoline was able to maintain selectivity, the system was kept in the optimized conditions (flow rate $2.3 \mathrm{~mL} \mathrm{~min}^{-1}$, room temperature, system pressure of $30 \mathrm{psi}$, and $1 \mathrm{wt} \%$ quinoline) for $45 \mathrm{~min}$ (Figure 7). A C\&K solution of $1 \mathrm{mg} \mathrm{mL} \mathrm{m}^{-1}$ was used for this experiment. Reaction selectivity and quinoline consumption were monitored by GC.

The reaction had excellent results in the first $20 \mathrm{~min}$ (Figure 7). The catalyst performance was not stable after that period due to a significant reduction in selectivity, $80 \%$ after $25 \mathrm{~min}$ and $60 \%$ after $35 \mathrm{~min}$. The drop in selectivity can be ascribed to quinoline leaching by the solvent flow. The catalyst can be flushed away during continuous-flow reaction regenerating the reactive catalyst.

In order to investigate how long the catalyst remains at the same selectivity producing pure cafestol, 1 wt \% quinoline was added to the $\mathrm{C} \& \mathrm{~K}$ mixture every $20 \mathrm{~min}$. The selectivity was monitored by GC-MS (Figure 8). The reposition of quinoline stabilized the catalyst performance for $4800 \mathrm{~s}$ with excellent conversion (>99\%) and selectivity (>99\%). During the entire 80 min-long experiment, there was no significant reduction in catalyst activity. The test produced $258 \mathrm{mg}$ of cafestol, starting with $\mathrm{C} \& \mathrm{~K}$ at $1 \mathrm{mg} \mathrm{mL}^{-1}$.

Effect of C\&K Concentration in Continuous-Flow Hydrogenation. The concentration of $\mathrm{C} \& \mathrm{~K}$ solutions was gradually increased $\left(1,10,20\right.$, and $\left.50 \mathrm{mg} \mathrm{mL}^{-1}\right)$ and introduced into the H-cube continuous-flow system by a mini HPLC pump. The results were collected under steady-

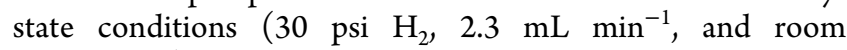
temperature) and analyzed by GC-MS. The selectivity was kept constant up to $20 \mathrm{mg} \mathrm{mL}^{-1} \mathrm{C} \& \mathrm{~K}$ (Figure 9A), with the formation of cafestol only. The increase in concentration to 50 $\mathrm{mg} \mathrm{mL} \mathrm{m}^{-1}$ possibly saturates the catalytic sites and decreases conversion to $91 \%$ besides the formation of by-products (3\%) (Figure 9B).

Batch versus Continuous-Flow Productivity. The productivities for batch and continuous-flow reactions were calculated with eq 1 , considering that the best condition for cafestol production was achieved in both processes (Table 4). The most successful batch reaction was the one using the $\mathrm{Pd} /$ 
A) Abundance $\left(10^{5}\right)$

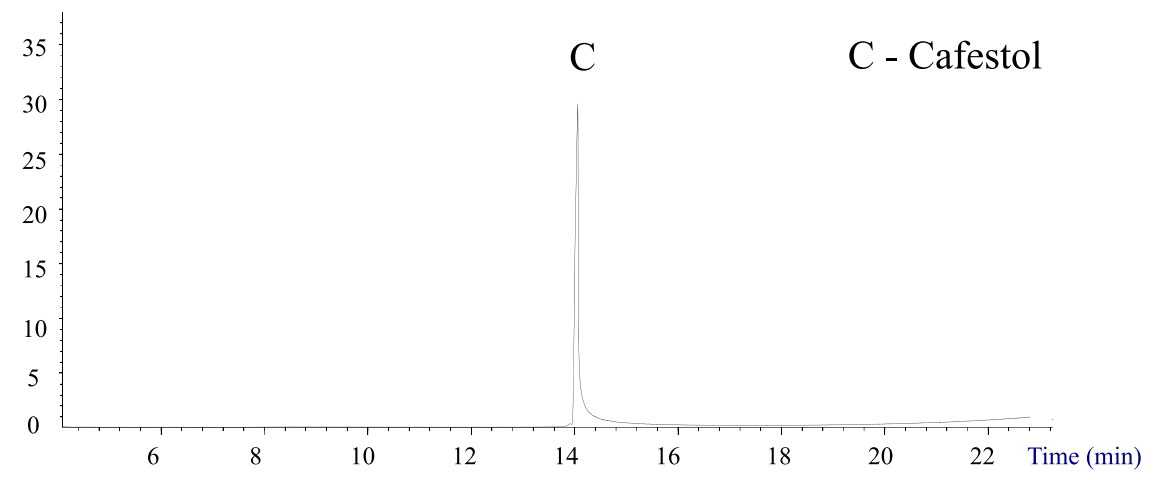

B)

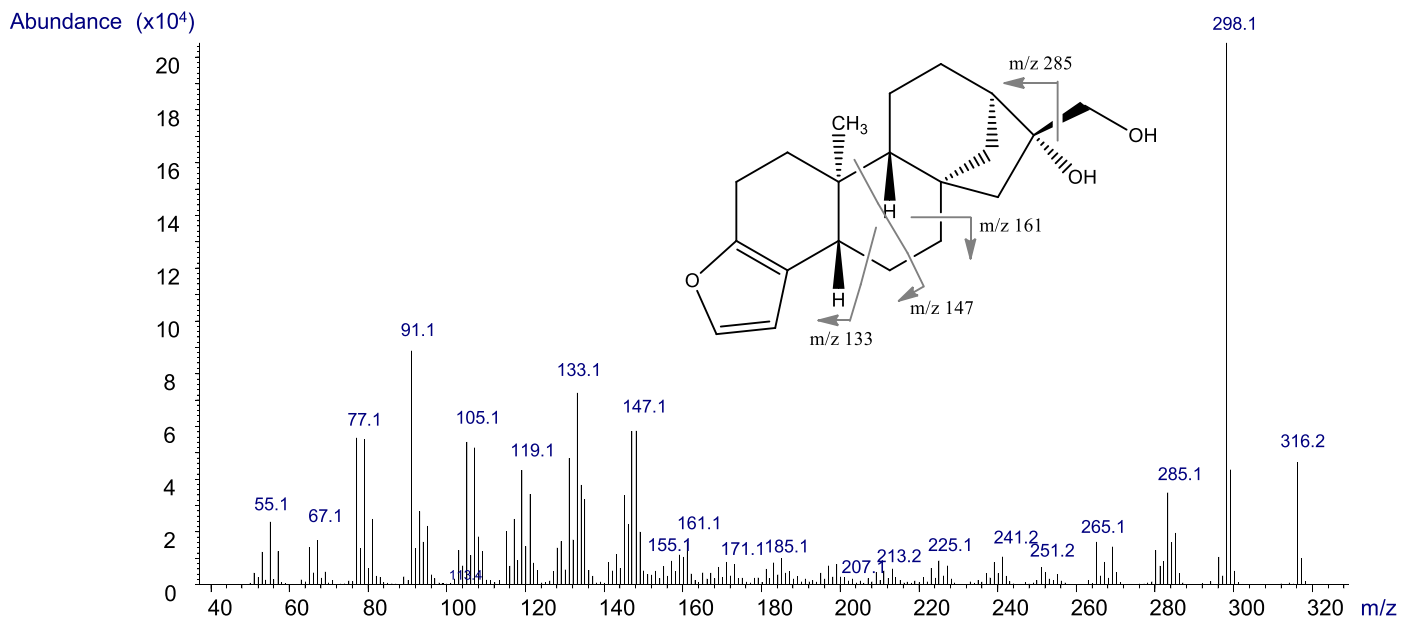

Figure 4. (A) GC-MS chromatograms of $9.8 \mathrm{~s}$ hydrogenation reaction under continuous-flow conditions using Pd/C $5 \%$ with 1 wt \% quinoline. (B) Mass spectrum of cafestol (14 min).

C $10 \%$ catalyst with 1 wt $\%$ quinoline and 10 min of reaction time (see Table 1, entry 2). For the continuous-flow hydrogenation, the best results were achieved using the $\mathrm{Pd} /$ C 5\% catalyst cartridge with 1 wt \% quinoline and $9.8 \mathrm{~s}$ of reaction time (see Table 2, entry 1 ). The productivities were calculated considering the cafestol mass-produced in both processes (calculated by HPLC. Chromatograms shown in the Supporting Information), the mass of the $\mathrm{Pd} / \mathrm{C}$ catalyst used in both methods, and the reaction times.

$$
\text { productivity }=\frac{\mathrm{mmol} \text { cafestol }}{\text { reaction time }(\mathrm{h}) \times \text { catalyst load }(\mathrm{mg})}
$$

Although the H-Cube Mini Plus uses cartridges with large catalyst mass $(133 \mathrm{mg})$, it does not influence the reaction conversion due to the short contact time promoted by the continuous-flow system. Even when the batch reaction had a catalyst mass 20 times higher, the continuous-flow process managed to be more productive, providing pure cafestol 60 times faster than the batch process.

\section{CONCLUSIONS}

Two processes to obtain pure cafestol from kahweol through heterogeneous catalytic hydrogenation were carried out by batch and continuous-flow hydrogenation using $\mathrm{Pd} / \mathrm{C}$ catalysts with $1 \mathrm{wt} \%$ quinoline. Thus far, only batch hydrogenation of kahweol from the $\mathrm{C} \& \mathrm{~K}$ mixture has been done in ambient conditions using Lindlar catalysts poisoned with lead acetate, a unfriendly compound.

In batch experiments, the conversion is dependent on the type of palladium support. From several palladium catalysts tested, $\mathrm{Pd} / \mathrm{C}$ obtained the best selectivity results, including the carbon black-supported Pd catalyst coated by a covalently tethered $\mathrm{SiO}_{2}$ shell with mesoporous texture $\left(\mathrm{Pd} / \mathrm{CB} @ \mathrm{SiO}_{2}\right)$, synthesized in this work.

Quinoline was fundamental for the reactivity control of palladium catalysts with considerable improvement in selectivity.

\section{EXPERIMENTAL SECTION}

Materials and Reagents. Green Arabica coffee beans were purchased from a farm in São José do Vale do Rio Preto, Rio de Janeiro State, Brazil, located at latitude $22^{\circ} 11^{\prime} 40^{\prime \prime} \mathrm{S}$, $42^{\circ} 58^{\prime} 22^{\prime \prime} \mathrm{W}$ and altitude $650-850 \mathrm{~m}$, in 2016. Potassium hydroxide ( $\mathrm{KOH}$, Isofar, PA), methanol $(\mathrm{MeOH}, \mathrm{Scilab}$, 99.9\%), and tert-butyl methyl ether (TBME, Tedia, 99.8\%) were used in C\&K extraction. Flash silica gel 60 (Vetec), hexane (Tedia, ACS), and ethyl acetate (Tedia, ACS) were used in C\&K purification by column chromatography (CC). Ethanol (EtOH, Sigma, 95.0\%), quinoline (Sigma, 98.0\%), palladium catalysts (Sigma), and Pd/C 5\% and 10\% CatCart (ThalesNano) were used for hydrogenation reactions. The aluminum TLC plates, silica gel coated with the fluorescent indicator $\mathrm{F}_{254}(20 \times 20 \mathrm{~cm})$ were purchased from Merck. 
A)

Abundance $\left(\times 10^{5}\right)$

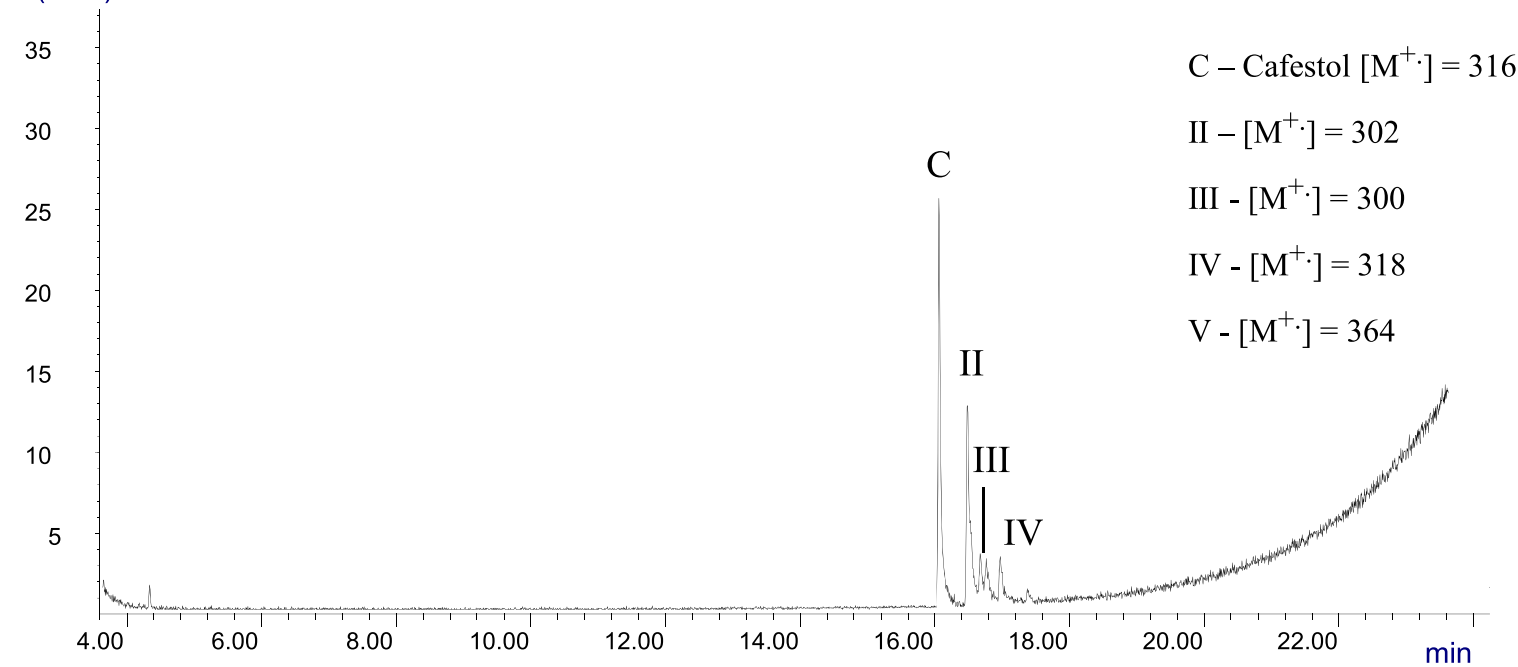

Abundance $\left(\times 10^{5}\right)$

B)

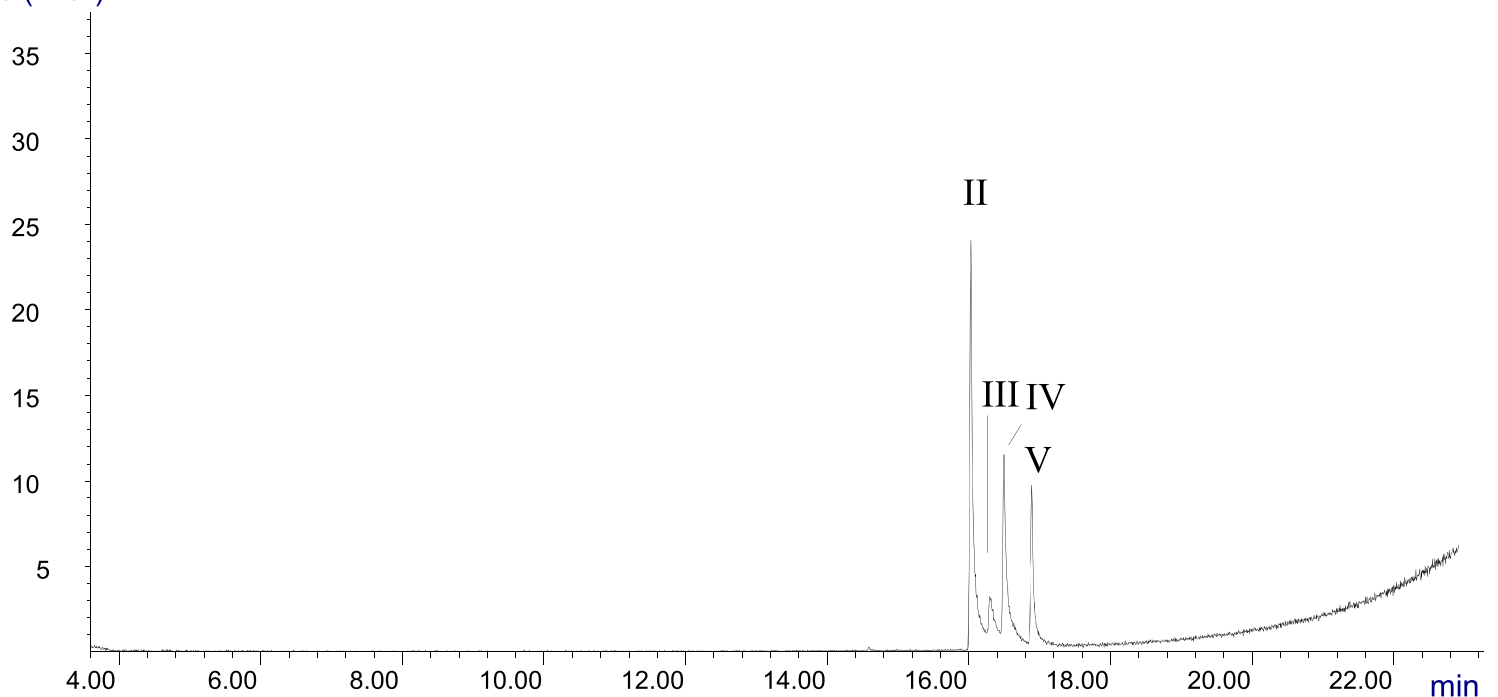

Figure 5. GC-MS chromatograms of hydrogenation reactions under continuous-flow conditions using Pd/C 5\% with 1 wt $\%$ quinoline. (A) $56.5 \mathrm{~s}$ reaction time and (B) 113.1 s. Peaks II, III, IV, and V are FRHP (see Figure 3).

Table 3. Continuous-Flow Hydrogenation of C\&K with Pd/C at Different Times, with or without Quinoline ${ }^{a}$

\begin{tabular}{|c|c|c|c|c|c|c|c|c|}
\hline entry & catalyst & flow rate $\left(\mathrm{mL} \min ^{-1}\right)$ & residence time $(s)$ & quinoline $(\% \mathrm{w} / \mathrm{w})$ & conversion (\%) & cafestol selectivity $(\%)^{b}$ & DP (\%) & FRHP (\%) \\
\hline 1 & $\mathrm{Pd} / \mathrm{C} 5 \%$ & 2.3 & 9.8 & 0 & 89 & 72 & 0 & 17 \\
\hline 2 & $\mathrm{Pd} / \mathrm{C} 5 \%$ & 2.3 & 9.8 & 1 & 100 & $>99$ & 0 & $<1$ \\
\hline 3 & $\mathrm{Pd} / \mathrm{C} 5 \%$ & 0.4 & 56.5 & 0 & 100 & $<1$ & 0 & $>99$ \\
\hline 4 & $\mathrm{Pd} / \mathrm{C} 5 \%$ & 0.4 & 56.5 & 1 & 100 & 61 & 0 & 39 \\
\hline 5 & $\mathrm{Pd} / \mathrm{C} 5 \%$ & 0.2 & 113.1 & 0 & 100 & $<1$ & 0 & $>99$ \\
\hline 6 & $\mathrm{Pd} / \mathrm{C} 5 \%$ & 0.2 & 113.1 & 1 & 100 & $<1$ & 0 & $>99$ \\
\hline
\end{tabular}

${ }^{a}$ Reaction conditions: solution of $\mathrm{C} \& \mathrm{~K}$ in ethanol $\left(1 \mathrm{mg} \mathrm{mL}^{-1}\right), 1.04 \mu \mathrm{L}$ of quinoline $\left(1 \mathrm{wt} \%\right.$ catalyst), $113 \mathrm{mg}$ of $\mathrm{Pd} / \mathrm{C}$ catalyst, $25^{\circ} \mathrm{C}$, flow rates of $2.3,0.4$, and $0.2 \mathrm{~mL} \mathrm{~min}^{-1}$. DP: dehydration products; FRHP: furan ring hydrogenation products. ${ }^{b}$ Selectivity values based on GC absolute area.

Isolation of the C\&K Mixture and Cafestol Acquirement. The procedure used for isolation of the C\&K mixture from green coffee beans was performed according to Novaes et al. $^{27}$ The mixture of C\&K used in this work was obtained as a white solid ( $>99 \%$ by GC) with a mass ratio of 3:1 between cafestol and kahweol, respectively. The method was able to isolate $5.1 \mathrm{~g} \mathrm{~kg}^{-1}$ of $\mathrm{C} \& \mathrm{~K}$ from green coffee beans.
The cafestol standard used for the calibration curve was obtained by a continuous-flow hydrogenation protocol reported in this work (see Table 2, entry 1) followed by purification by column chromatography (CC) to remove quinoline. The purification was performed using a glass column $(60 \times 2.5 \mathrm{~cm})$ fully packed with $30 \mathrm{~g}$ of flash silica gel suspended in hexane. Five hundred milligrams of unpurified cafestol was mixed with $2 \mathrm{~g}$ of flash silica gel and suspended in 
A)

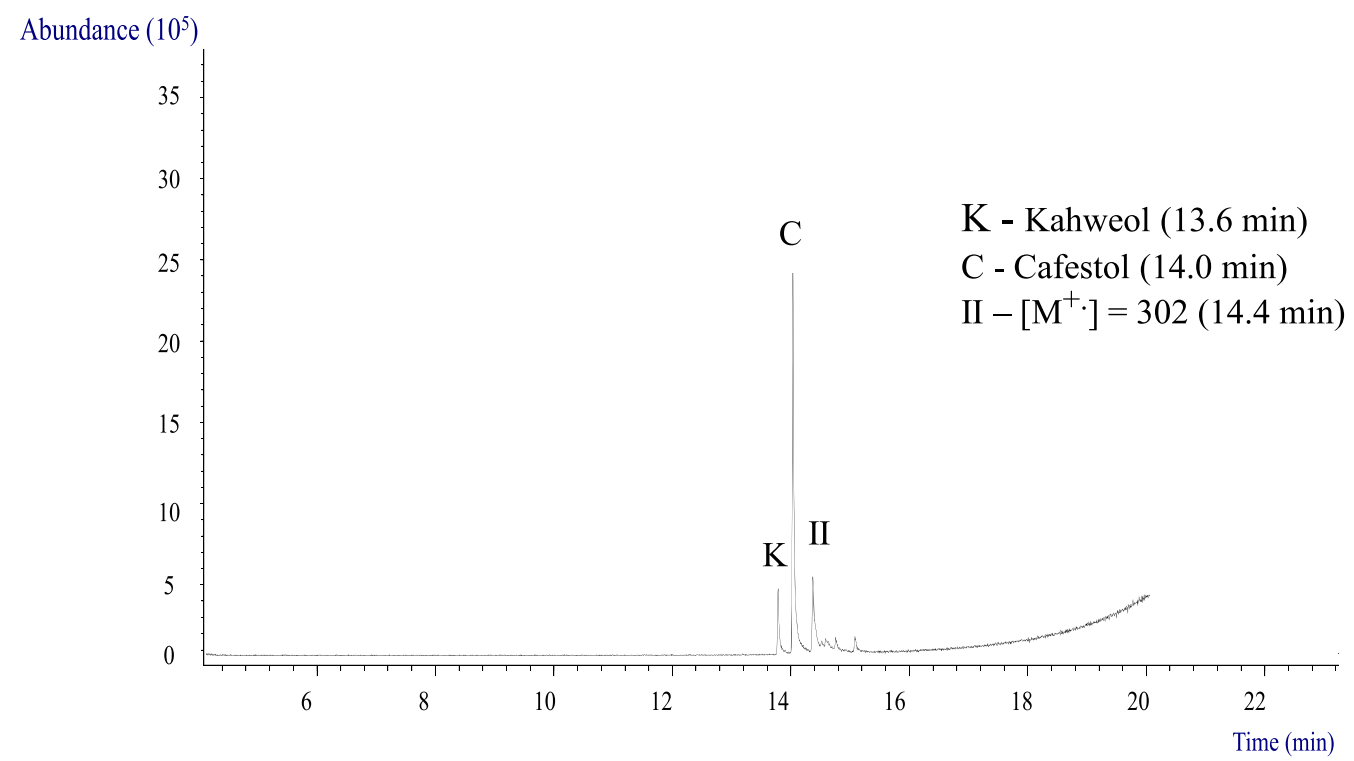

B)

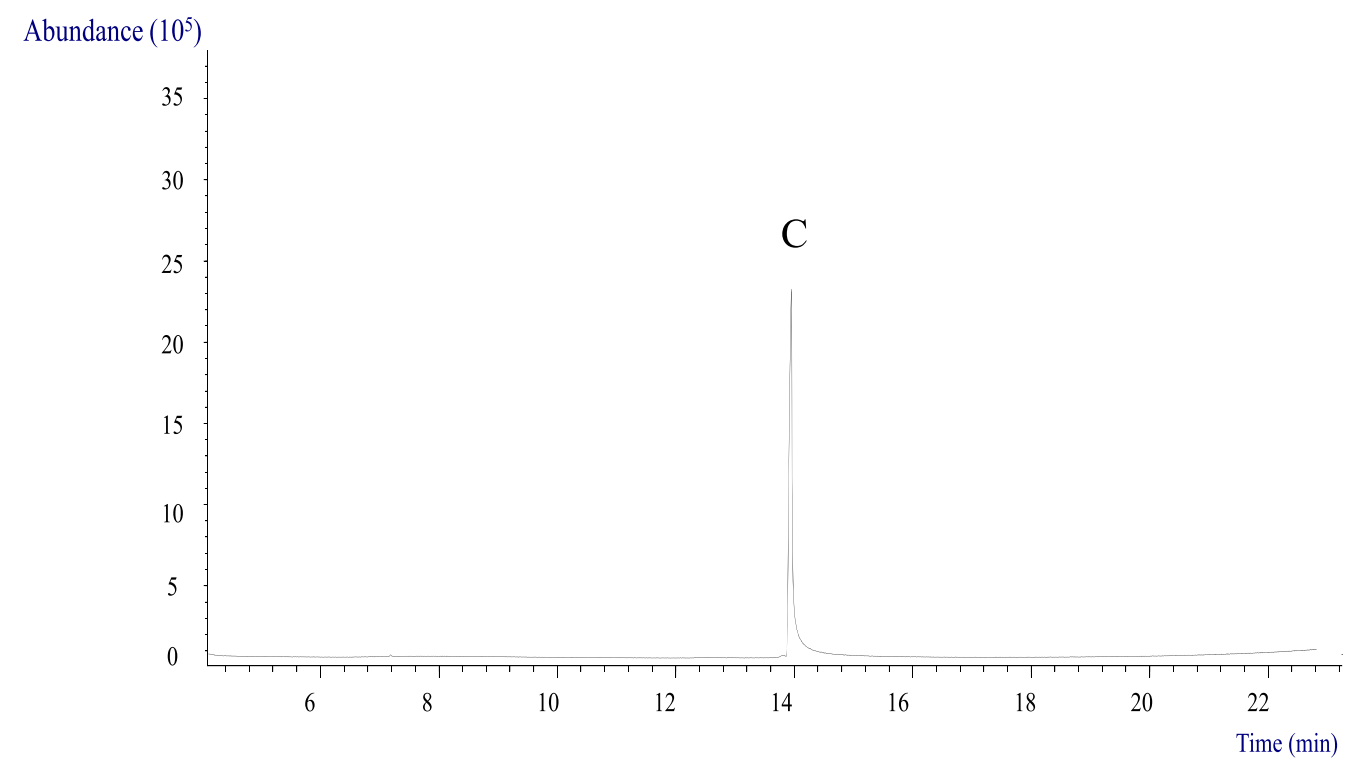

Figure 6. GC-MS chromatograms of $9.8 \mathrm{~s}$ hydrogenation reaction under continuous-flow conditions (A) without quinoline and (B) with 1 wt $\%$ quinoline. Peak II - FRHP (see Figure 3).

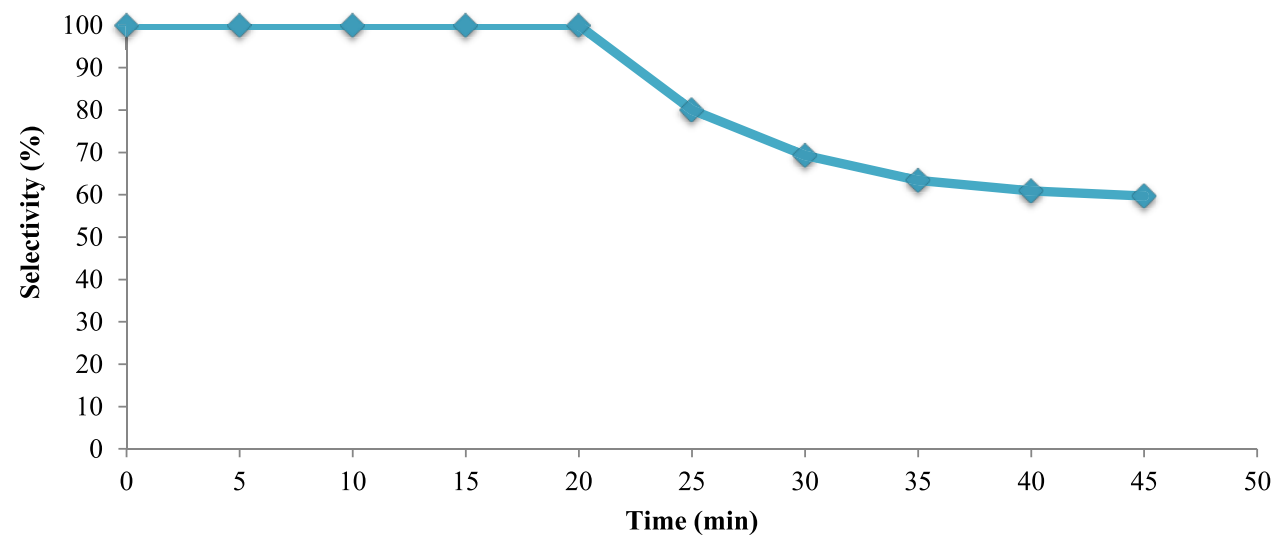

Figure 7. Dependence of quinoline percentage on reaction selectivity of C\&K hydrogenation continuous-flow reaction in the optimized conditions (flow rate $2.3 \mathrm{~mL} \mathrm{~min}^{-1}$, room temperature, system pressure of $30 \mathrm{psi}$, and $1 \mathrm{wt} \%$ quinoline). 


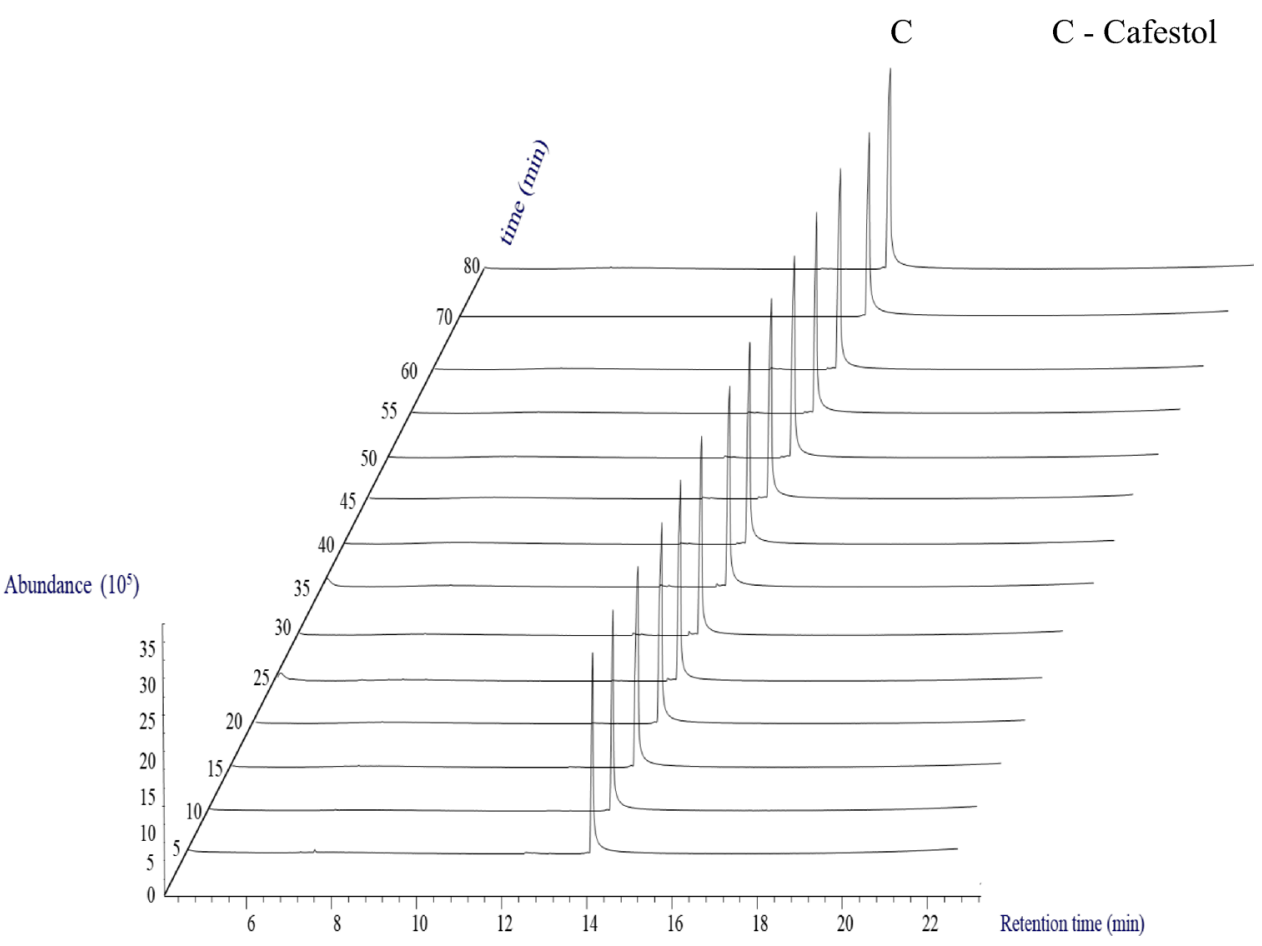

Figure 8. GC-MS chromatograms of continuous-flow hydrogenation of cafestol and kahweol mixture during the 80 min-long experiment.

$50 \mathrm{~mL}$ of methanol. After, the solvent was removed under vacuum, and the material was applied at the top of the column. Hexane/ethyl acetate (10:0 $(200 \mathrm{~mL}), 9: 1(200 \mathrm{~mL}), 8: 2(200$ $\mathrm{mL})$, and $1: 1 \mathrm{v} / \mathrm{v}(600 \mathrm{~mL}))$ were used as mobile phases in gradient mode at atmospheric pressure (flow rate $\nu=2.5 \mathrm{~cm}$ $\left.\mathrm{min}^{-1}\right)$. Pure cafestol was collected from the hexane/ethyl acetate phase $1: 1 \mathrm{v} / \mathrm{v}$ giving $420 \mathrm{mg}$ of white solid ( $>99 \%$ by GC). NMR spectral data and melting point value are in accordance with Novaes et al. ${ }^{27}$

Cafestol $\left(\mathrm{C}_{20} \mathrm{H}_{28} \mathrm{O}_{3}\right)$ : white solid; m.p. $153.5-154.0{ }^{\circ} \mathrm{C} ;{ }^{1} \mathrm{H}$ $\operatorname{NMR}\left(500 \mathrm{MHz}, \mathrm{CDCl}_{3}, \delta \mathrm{ppm}\right): 7.25(1 \mathrm{H}, \mathrm{d}, J=1.8 \mathrm{~Hz}$, H19), 6.22 (1H, d, $J=1.8 \mathrm{~Hz}, \mathrm{H} 18), 5.31(1 \mathrm{H}, \mathrm{s}, \mathrm{C} 16-\mathrm{OH})$, $3.82(1 \mathrm{H}, \mathrm{d}, J=11.1 \mathrm{~Hz}, \mathrm{H} 17 \mathrm{a}), 3.70(1 \mathrm{H}, \mathrm{d}, J=11.1 \mathrm{~Hz}$, $\mathrm{H} 17 \mathrm{~b}), 2.62(2 \mathrm{H}, \mathrm{dd}, J=5.8,2.7 \mathrm{~Hz}, \mathrm{H} 2), 2.27(1 \mathrm{H}, \mathrm{dq}, J=$ 12.6, $2.7 \mathrm{~Hz}, \mathrm{H} 5), 2.07-2.03$ (3H, m, H13, H1, H14), 1.82 $(1 \mathrm{H}$, ddd, $J=12.9,6.2,3.1 \mathrm{~Hz}, 455 \mathrm{H6}), 1.74-1.51(10 \mathrm{H}, \mathrm{m}$, H6, H7, H11, H12, H14, H15), 1.27-1.23 (1H, m, H1), 1.19 $(1 \mathrm{H}, \mathrm{d}, J=7.7 \mathrm{~Hz}, \mathrm{H} 9), 0.84(3 \mathrm{H}, \mathrm{s}, \mathrm{H} 20) .{ }^{13} \mathrm{C} \mathrm{NMR}(500$ $\mathrm{MHz}, \mathrm{CDCl}_{3}, \delta \mathrm{ppm}$ ): 148.8 (C, C3), 457140.7 (CH, C19), 120.2 (C, C4), 108.4 (CH, C18), 82.1 (C, C16), $66.4\left(\mathrm{CH}_{2}\right.$, C17), $53.4458\left(\mathrm{CH}_{2}, \mathrm{C} 15\right), 52.2(\mathrm{CH}, \mathrm{C} 9), 45.5(\mathrm{CH}, \mathrm{C} 13)$, 44.8 (C, C8), 44.3 ( $\mathrm{CH}, \mathrm{C} 5), 41.0\left(\mathrm{CH}_{2}, \mathrm{C} 7\right), 38.7$ (C, C10), $38.3\left(\mathrm{CH}_{2}, \mathrm{C} 14\right), 35.8\left(\mathrm{CH}_{2}, \mathrm{C} 1\right), 26.2\left(\mathrm{CH}_{2}, \mathrm{Cl}_{2}\right), 23.2$ $\left(\mathrm{CH}_{2}, \mathrm{C} 6\right), 20.8\left(\mathrm{CH}_{2}, \mathrm{C} 2\right), 19.1\left(\mathrm{CH}_{2}, \mathrm{C} 11\right), 13.5\left(\mathrm{CH}_{3}\right.$, $\mathrm{C} 20)$.

Preparation of the $\mathrm{Pd} / \mathrm{CB} @ \mathrm{SiO}_{2}$ Catalyst. The carbon black-supported Pd catalyst, coated by a covalently tethered $\mathrm{SiO}_{2}$ shell with mesoporous texture $\left(\mathrm{Pd} / \mathrm{CB} @ \mathrm{SiO}_{2}\right)$, was prepared according to a previously described protocol: ${ }^{24,25}$ one gram of carbon black (CB) support dispersed in $100 \mathrm{~mL}$ of $\mathrm{Na}_{2} \mathrm{CO}_{3} 2.5$ wt \% aqueous solution was stirred for $15 \mathrm{~min}$ at room temperature. Fifty six milligrams of $\mathrm{Na}_{2} \mathrm{PdCl}_{4}$ (corresponding to a theoretical $2.0 \mathrm{wt} \%$ loading) dissolved in $20 \mathrm{~mL}$ of distilled water was added dropwise to the suspension within $1 \mathrm{~h}$. Five grams of $\mathrm{NaBH}_{4}$ diluted in $20 \mathrm{~mL}$ of distilled water was then added. The suspension was stirred for $2 \mathrm{~h}$. Finally, the catalyst $(\mathrm{Pd} / \mathrm{CB})$ was filtered out, washed with distilled water $(1 \mathrm{~L})$, and dried. Two grams of CB was introduced into a 250 $\mathrm{mL}$ round-bottom flask containing $100 \mathrm{~mL}$ of toluene. Six milliliters of $\mathrm{SOCl}_{2}$ was added, and the mixture was heated for $5 \mathrm{~h}\left(120^{\circ} \mathrm{C}\right)$. Then, it was filtered out and extensively washed with toluene $(500 \mathrm{~mL})$. One gram of the resulting material (CB-Cl) was introduced into a $250 \mathrm{~mL}$ round-bottom flask containing $100 \mathrm{~mL}$ of dichloromethane. One milliliter of APTES was added, and the mixture was stirred for $24 \mathrm{~h}$ at room temperature. Finally, the material (CB-APTES) was filtered out, washed with dichloromethane $(250 \mathrm{~mL})$ and methanol $(250 \mathrm{~mL})$, and dried overnight under vacuum at 100 ${ }^{\circ} \mathrm{C}$. A nominal 2.5 wt \% Pd $\left(71 \mathrm{mg} \mathrm{Na} \mathrm{PdCl}_{4}\right)$ amount was engaged to counterbalance the dilution effects of the covering layer and so to keep the same wt \% Pd loading. Two hundred and fifty milligrams of Pd/CB-APTES was introduced into a $100 \mathrm{~mL}$ round bottom flask containing $25 \mathrm{~mL}$ of distilled water. Then, $10 \mathrm{~mL}$ of $\mathrm{NaOH}(0.1 \mathrm{M})$ was added, and the mixture was sonicated for $10 \mathrm{~min}$. To this suspension, $0.571 \mathrm{~g}$ of $\mathrm{CTAB}$ was added and the solution was heated at $60{ }^{\circ} \mathrm{C}$. Seventy milliliters of TEOS was added dropwise within $30 \mathrm{~min}$. This suspension was further stirred for $3 \mathrm{~h}$ and $30 \mathrm{~min}$ and then charged into a propylene bottle, which was closed tightly and heated at $100{ }^{\circ} \mathrm{C}$ for 3 days. The product was filtered out, washed with ethanol $(250 \mathrm{~mL})$, and dried at $100{ }^{\circ} \mathrm{C}$ overnight. In the end, the $\mathrm{CTAB}$ template was removed by refluxing in ethanol the solid material $\left(\mathrm{Pd} / \mathrm{CB} @ \mathrm{SiO}_{2}\right)$ for $24 \mathrm{~h}$.

The solid catalyst was characterized by X-ray photoelectron spectroscopy (XPS), transmission electron microscopy (TEM), thermogravimetric analysis (TGA), elemental analyses (ICP), and $\mathrm{N}_{2}$ physisorption according to the protocol described by Haynes et al. ${ }^{24}$

Procedure for Batch Hydrogenation Experiments. Hydrogenation experiments in the batch mode were carried out using a shaker hydrogenation apparatus (Parr) (see Figure $\mathrm{S} 1$ in the Supporting Information). In a $500 \mathrm{~mL}$ reaction 
A)

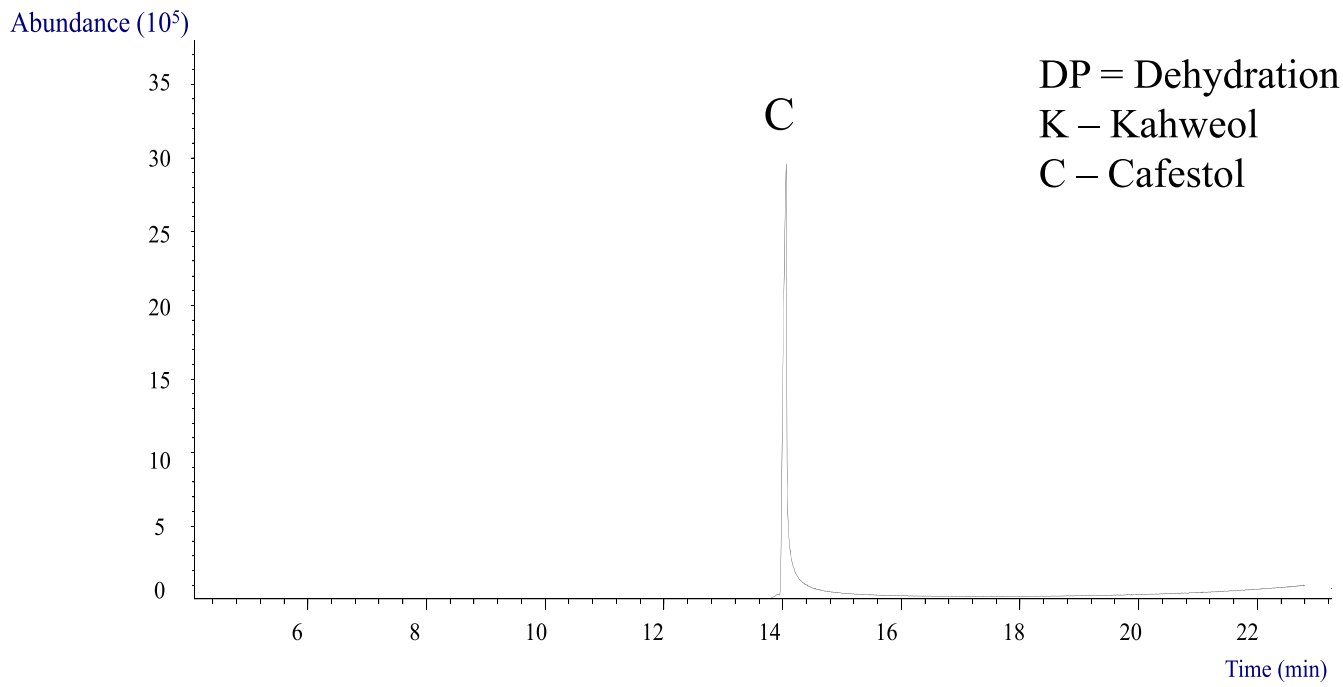

B)

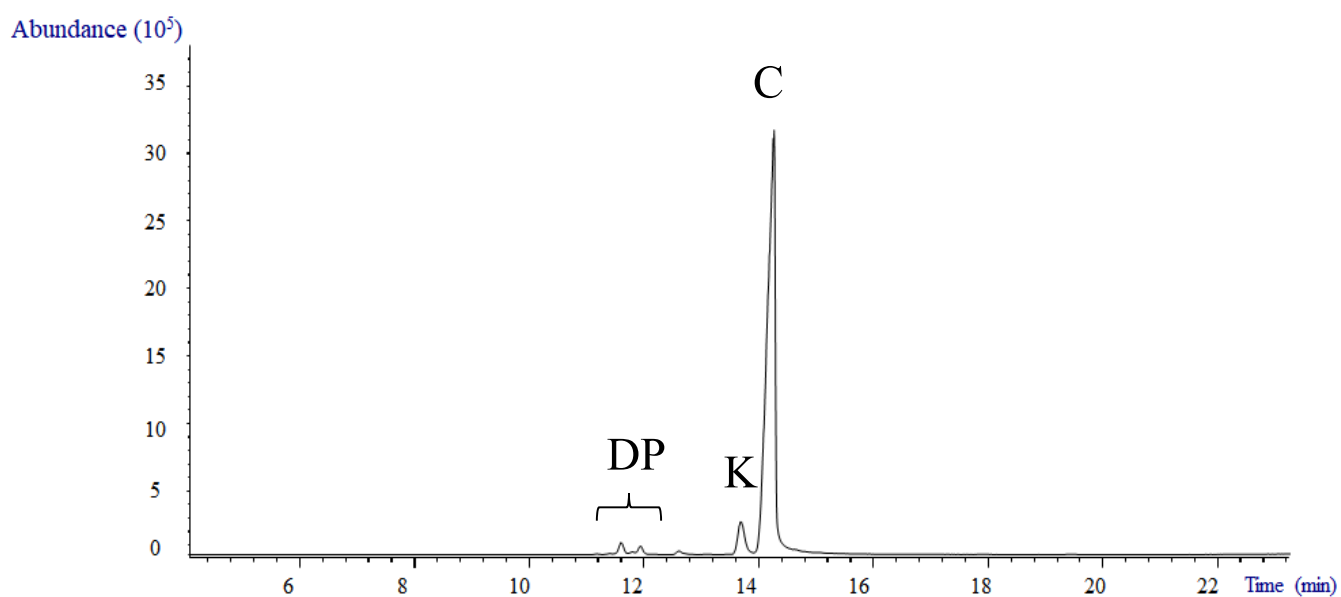

Figure 9. GC-MS chromatograms of $9.8 \mathrm{~s}$ hydrogenation reaction under continuous-flow conditions (A) with $20 \mathrm{mg} \mathrm{mL} \mathrm{m}^{-1} \mathrm{C} \& \mathrm{~K}$ solution and 1 wt $\%$ quinoline and (B) with $50 \mathrm{mg} \mathrm{mL}^{-1} \mathrm{C} \& \mathrm{~K}$ solution and $1 \mathrm{wt} \%$ quinoline (DP - dehydration products. See Figure 2).

Table 4. Batch and Continuous-Flow Productivities

$\begin{array}{ccccc} & \text { cafestol }(\mathrm{mmol}) & \text { reaction time }(\mathrm{h}) & \text { catalyst load }(\mathrm{mg}) & \text { productivity }\left(\mathrm{mmol} \mathrm{h}^{-1} \mathrm{mg}^{-1}\right) \\ \text { batch } & 0.00450 & 0.1667 & 5 & 0.0054 \\ \text { continuous flow } & 0.00507 & 0.0027 & 113 & 0.0166\end{array}$

bottle, $100 \mathrm{mg}$ of C\&K was added with $5 \mathrm{mg}$ of Pd catalyst with 1,3 , and 5 wt $\%$ quinoline and $100 \mathrm{~mL}$ of ethanol $95 \%$. After purging three times, $30 \mathrm{psi}_{2}$ was added and shaking was started. The reaction mixture was kept at room temperature for 5, 10, 30, and $60 \mathrm{~min}$. Then, the shaking was stopped, and $\mathrm{H}_{2}$ pressure was released. The resultant mixture was filtered to remove the catalyst.

Procedure for Continuous-Flow Experiments. Continuous-flow experiments were performed in a high-pressure continuous-flow hydrogenator reactor $\mathrm{H}$-Cube Mini Plus (ThalesNano; see Figure S7 in the Supporting Information), which supplied $\mathrm{a}_{2}$ flow produced from electrolysis of water to the central reactor module in which a $30 \mathrm{~mm}$ catalyst cartridge was installed, packed with $113 \mathrm{mg}$ of $\mathrm{Pd} / \mathrm{C}$ catalyst. The dead volume of the system was $0.131 \mathrm{~mL}$. The corresponding total flow-through volume (including feed lines, reactor, and product lines) was $3.13 \mathrm{~mL}$. The operational temperature was $25{ }^{\circ} \mathrm{C}$. First, pure ethanol was pumped through the system before reaching the set temperature (25
${ }^{\circ} \mathrm{C}$ ) and pressure (30 psi). The system was operated with ethanol $95 \%$ at different flow rates $(0.2,0.4$, and $2.3 \mathrm{~mL}$ $\mathrm{min}^{-1}$ ) and hydrogen flow around $70 \mathrm{~mL} \min ^{-1}$. Once the reaction conditions were stable, ethanol was exchanged by a solution of $\mathrm{C} \& \mathrm{~K}$ in ethanol $\left(1,10,20\right.$, and $\left.50 \mathrm{mg} \mathrm{mL}^{-1}\right)$ with $1.04 \mu \mathrm{L}$ of quinoline. Then, each reaction was operated for 9.8 , 56.5 , and $113.1 \mathrm{~s}$ as a function of corresponding flow rates of 2.3, 0.4 , and $0.2 \mathrm{~mL} \mathrm{~min}^{-1}$. Afterward, the samples were collected and analyzed by GC-MS.

GC-MS-FID and HPLC-UV Analyses. The reactions were analyzed, after filtration, using an Agilent 6890 gas chromatograph equipped with an FID detector and a mass spectrometer (MS) Agilent 5973 N. Helium (99.9992\% purity) was used as carrier gas at $2 \mathrm{~mL} \mathrm{~min}^{-1}$ in constant flow mode in a DB-17HT capillary column (50\% phenyl and $50 \%$ methylsiloxane, $10 \mathrm{~m}$ $\times 0.25 \mathrm{~mm} \times 0.15 \mu \mathrm{m}$, Agilent Technologies). The injection was made in pulsed split mode $(1: 10)$ at $330{ }^{\circ} \mathrm{C}, 1.0 \mu \mathrm{L}$ of each reaction solution. The oven temperature was set at 90 $\left(0.25 \mathrm{~min}\right.$ ) to $300{ }^{\circ} \mathrm{C}$ in $10{ }^{\circ} \mathrm{C} \mathrm{min}^{-1}$ for both the FID (at 300 
${ }^{\circ} \mathrm{C}$ ) and MSD (transfer line at $330{ }^{\circ} \mathrm{C}$ ). Mass spectra were obtained in scan mode $(45-800 \mathrm{Da})$. The identification of cafestol was performed by comparison of the retention times with pure standard and mass spectral acquisition.

Cafestol quantification for batch and continuous-flow productivity calculation was performed using an HPLC system (Agilent, 1200 series) with a Quat pump (Agilent, G1311A), an autosampler (Agilent, G1329A), and a diode array detector (DAD, Agilent, G1315D). A C-18 column (Zorbax, $150 \mathrm{~mm} \times$ $4.6 \mathrm{~mm}, 5 \mu \mathrm{m}$ particle size, and $100 \AA$ pore size) was used at room temperature. The mobile phase was water (A) and acetonitrile (B) 55:45 in isocratic mode. The flow was set at $0.7 \mathrm{~mL} \mathrm{~min}{ }^{-1}$. Peaks were monitored at $230 \mathrm{~nm}$. The calibration curve was determined in the range of $10-90 \mathrm{mg}$ $\mathrm{mL}^{-1}$ performed in triplicate, using a cafestol standard at 25 $\mathrm{mg} \mathrm{L}^{-1}$ in methanol. The correlation coefficient of the linear regression was $>0.99$.

Quantitative Determination of Palladium Using Energy-Dispersive X-ray Fluorescence (EDXRF). The quantity of $\mathrm{Pd}$ present in the solid and liquid samples was determined using an energy-dispersive X-ray fluorescence (EDXRF) spectrometer from Bruker Nano GmbH (M4 Tornado, Germany). On this typical commercial spectrometer, the $\mathrm{X}$-ray tube is an $\mathrm{Rh}$ micro-focus side window powered by a low-power HV-generator and cooled by air. The spot size of 25 $\mu \mathrm{m}$ is obtained using a poly-capillary lens in a Mo $\mathrm{K} \alpha$ mode. The X-ray generator was operated at $50 \mathrm{kV}$ and $600 \mu \mathrm{A}$, and different filters were used to reduce the background $(100 \mu \mathrm{m}$ $\mathrm{Al} / 50 \mu \mathrm{mTi} / 25 \mu \mathrm{m} \mathrm{Cu}$ ). The energy resolution of a detector (thermoelectrically cooled silicon-drift-detector) was $142 \mathrm{eV}$ for $5.9 \mathrm{keV}(\mathrm{Mn} \mathrm{K} \alpha)$. Measurements were carried out under 20 mbar vacuum conditions. An in-built camera allows visualizing the operating area and permits the analysis in a fully automated mode. According to the required resolution, the counting time and the scanning spatial resolution could be freely selected. The sample was placed directly on a sample holder $(360 \mathrm{~mm} \times 260 \mathrm{~mm})$, which was attached to a stage translatable along the $X Y$. The scanning step size used was 25 $\mu \mathrm{m}$, and the time per analyzed point was $0.5 \mathrm{~ms} \times 3$ cycles. Each selected area was analyzed over a period to accumulate sufficient data points for high-resolution mapping. Data output was obtained through the X-ray intensities of specific X-ray peaks corresponding to the element signals measured in each point defined by its $X$ and $Y$ coordinates $(\mu \mathrm{m})$. The data were converted using the software's function into a data matrix, from which $X Y$ contour maps (two-dimensional maps) of the data were generated for each element.

Analyses performed by XRF for batch and continuous-flow samples collected at the packed-bed reactor outlet after the hydrogenation reaction, both in natura and concentrated under an inert solid, showed no detectable palladium concentration (see Figure S15 in the Supporting Information for further details). Aiming to determine the metal composition of the palladium supported on active carbon catalyst at the end of reactions, an X-ray diffraction (XRD) analysis of palladium was also carried out, as evidenced by the presence of both $\mathrm{Pd}^{0}$ and $\mathrm{PdO}$, as a consequence of the hydrogenation reaction. These results demonstrate the robustness of the catalyst since no palladium leakage was evidenced in the reaction medium.

\section{ASSOCIATED CONTENT}

\section{Supporting Information}

The Supporting Information is available free of charge at https://pubs.acs.org/doi/10.1021/acsomega.0c01835.

Schematic illustrations of the batch and continuous-flow experiments, GC-MS chromatograms of hydrogenation experiments, mass spectra of the products, HPLC chromatograms of cafestol quantification analyses, and quantitative determination of the palladium on active carbon catalyst using energy-dispersive X-ray fluorescence analysis (PDF)

\section{AUTHOR INFORMATION}

\section{Corresponding Author}

Claudia Moraes Rezende - Instituto de Química, Universidade Federal do Rio de Janeiro, 21941-909 Rio de Janeiro, Brazil; 다이.org/0000-0003-2710-5702; Phone: +55-21-25627121; Email: crezende@iq.ufrj.br; Fax: +55-21-2562-7106

\section{Authors}

Fernanda Alves Lima - Instituto de Química, Universidade Federal do Rio de Janeiro, 21941-909 Rio de Janeiro, Brazil

Marco A. M. Bezerra - Instituto de Química, Universidade Federal do Rio de Janeiro, 21941-909 Rio de Janeiro, Brazil

Rodrigo Souza - Instituto de Química, Universidade Federal do Rio de Janeiro, 21941-909 Rio de Janeiro, Brazil

Ivaldo Itabaiana, Jr - Escola de Quimica, Departamento de Engenharia Bioquímica, Universidade Federal do Rio de Janeiro, 21941-895 Rio de Janeiro, Brazil; Centre National de la Recherche Scientifique, Chemistry, Villeneuve d'Ascq 59562, France; (1) orcid.org/0000-0003-0725-0881

Tommy Haynes - Institut IMCN Place Louis Pasteur, Universite catholique de Louvain, B-1348 Louvain-la-Neuve, Belgium

Sophie Hermans - Institut IMCN Place Louis Pasteur, Universite catholique de Louvain, B-1348 Louvain-la-Neuve, Belgium; (1) orcid.org/0000-0003-4715-7964

Robert Wojcieszak - Centre National de la Recherche Scientifique, Chemistry, Villeneuve d'Ascq 59562, France; - orcid.org/0000-0002-8956-5846

Fábio Junior M. Novaes - Instituto de Química, Universidade Federal do Rio de Janeiro, 21941-909 Rio de Janeiro, Brazil

Complete contact information is available at:

https://pubs.acs.org/10.1021/acsomega.0c01835

\section{Funding}

The authors thank the financial support from CAPES, CNPq, Embrapa Café, and FAPERJ. Chevreul Institute (FR 2638), Ministère de l'Enseignement Supérieur, de la Recherche et de l'Innovation, Région Hauts-de-France, Métropole Européenne de Lille, and FEDER are acknowledged for supporting and funding partially this work. This study was supported also by the French Government through the Programme Investissementd'Avenir (I-SITE ULNE/ANR-16-IDEX-0004 ULNE) managed by the Agence Nationale de la Recherche. F.J.M. Novaes thanks CAPES for providing post-doctoral fellowship PNPD/CAPES 2019 in the Chemistry Institute Federal University of Rio de Janeiro (Process 88887.320176/2019-00).

\section{Notes}

The authors declare no competing financial interest. 


\section{REFERENCES}

(1) Durán, C. A. A.; Tsukui, A.; Santos, F. K. F.; Martinez, S. T.; Bizzo, H. R.; Rezende, C. M. Café: Aspectos Gerais e seu Aproveitamento para além da Bebida. Rev. Virtual Quim. 2017, 9, 107-134.

(2) Speer, K.; Kölling-Speer, I. The lipid fraction of the coffee bean. Braz. J. Plant Physiol. 2006, 18, 201-216.

(3) Dias, R. C. E.; De Faria, A. F.; Mercadante, A. Z.; Bragagnolo, N.; Benassi, M. d. T. Comparison of Extraction Methods for Kahweol and Cafestol Analysis in Roasted Coffee. J. Braz. Chem. Soc. 2013, 24, 492-499.

(4) Tsukui, A.; Oigman, S. S.; Rezende, C. M. Óleo de Grãos de Café Cru: Diterpenos Cafestol e Caveol. Rev. Virtual Quim. 2014, 6, 16-33.

(5) Lee, K. J.; Choi, J. H.; Jeong, H. G. Hepatoprotective and antioxidant effects of the coffee diterpenes kahweol and cafestol on carbon tetrachloride-induced liver damage in mice. Food Chem. Toxicol. 2007, 45, 2118-2125.

(6) Sridevi, V.; Giridhar, P. Antioxidant potential of free diterpenes cafestol and kahweol rich extractives of coffee beans. Can. J. Basic Appl. Sci. 2015, 3, 78-84.

(7) Kim, J. Y.; Jung, K. S.; Lee, K. J.; Na, H. K.; Chun, H.-K.; Kho, Y.-H.; Jeong, H. G. The coffee diterpene kahweol suppress the inducible nitric oxide synthase expression in macrophages. Cancer Lett. 2004, 213, 147-154.

(8) Shen, C.-P.; Luo, J.-G.; Yang, M.-H.; Kong, L.-Y. Cafestol-Type Diterpenoids from the Twigs of Tricalysia fruticosa with Potential Anti-inflammatory Activity. J. Nat. Prod. 2015, 78, 1322-1329.

(9) Cavin, C.; Holzhaeuser, D.; Scharf, G.; Constable, A.; Huber, W. W.; Schilter, B. Cafestol and kahweol, two coffee specific diterpenes with anticarcinogenic activity. Food Chem. Toxicol. 2002, 40, 11551163.

(10) Savian, A. L.; Varella, F. T.; Athayde, M. L.; Da Silva, C. d. B. Desenvolvimento e avaliação preliminar da estabilidade de emulsão não-iônica $\mathrm{O} / \mathrm{A}$ contendoóleo de café verde como potencializador de fator de proteção solar. Rev. Bras. Farm. 2011, 91, 82-88.

(11) Lee, K. J.; Jeong, H. G. Protective effects of kahweol and cafestol against hydrogen peroxide-induced oxidative stress and DNA damage. Toxicol. Lett. 2007, 173, 80-87.

(12) De Roos, B.; Van der Weg, G.; Urgert, R.; Van de Bovenkamp, P.; Charrier, A.; Katan, M. B. Levels of Cafestol, Kahweol, and Related Diterpenoids in Wild Species of the Coffee Plant Coffea. J. Agric. Food Chem. 1997, 45, 3065-3069.

(13) Dias, R. C. E.; Campanha, F. G.; Vieira, L. G. E.; Ferreira, L. P.; Marraccini, P.; Benassi, M. D. T. Evaluation of Kahweol and Cafestol in Coffee Tissues and Roasted Coffee by a New High-Performance Liquid Chromatography Methodology. J. Agric. Food Chem. 2010, 58, $88-93$.

(14) Zhang, C.; Linforth, R.; Fisk, I. D. Cafestol extraction yield from different coffee brew mechanisms. Food Res. Int. 2012, 49, 2731.

(15) Haworth, R. D.; Jubb, A. H.; Mckenna, J. Cafestol. Part I. J. Chem. Soc. 1955, 1983-1989.

(16) Bertholet, R. Preparation of cafestol. United States Utility Patent US4,692,534A, 1987, 4, 692, 534.

(17) Nijhuis, T. A.; van Koten, G.; Moulijn, J. A. Optimized palladium catalyst systems for the selective liquid-phase hydrogenation of functionalyzed alkynes. Appl. Catal., A. 2003, 238, 259271.

(18) Chen, Y.; Wang, Z.; Mao, S.; Wang, Y. Rational design of hydrogenation catalysts using nitrogen-doped porous carbon. Chin. J. Catal. 2019, 40, 971-979.

(19) Cao, Y.; Mao, S.; Li, M.; Chen, Y.; Wang, Y. Metal/Porous Carbon Composites for Heterogeneous Catalysis: Old Catalysts with Improved Performance Promoted by N-Doping. ACS Catal. 2017, 7, $8090-8112$.

(20) De Souza, J. M.; Galaverna, R.; De Souza, A. A. N.; Brocksom, T. J.; Pastre, J. C.; De Souza, R. O. M. A.; De Oliveira, K. T. Impact of continuous flow chemistry in the synthesis of natural products and active pharmaceutical ingredients. An. Acad. Bras. Cienc. 2018, 90, $1131-1174$

(21) Guerreiro, G.; Suárez, M.; Moreno, G. Chemosystematic study of diterpenoids in green coffee beans. 20th International Colloquium on the Chemistry of Coffee. Paris: ASIC: 2005, 292-296.

(22) Lam, L. K. T.; Sparnins, V. L.; Wattenberg, L. W. Effects of Derivatives of Kahweol and Cafestol on the Activity of Glutathione STransferase in Mice. J. Med. Chem. 1987, 30, 1399-1403.

(23) Bruckner, R. Advanced Organic Chemistry: Reaction Mechanisms; 1st ed.; Elsevier: Academic Press: New York, 2001; pp. 104-106.

(24) Haynes, T.; Ersen, O.; Dubois, V.; Desmecht, D.; Nakagawa, K.; Hermans, S. Protecting a Pd/CB catalyst by a mesoporous silica layer. App.Catal., B. 2019, 241, 196-204.

(25) Haynes, T.; Dubois, V.; Hermans, S. Particle size effect in glucose oxidation with Pd/ CB catalysts. Appl. Catal., A 2017, 542, $47-54$.

(26) Yu, J. Discovery that quinoline and triphenylphosphine alter the electronic properties of hydrogenation catalysts. Chem. Commun. 1998, 1103-1104.

(27) Novaes, F. J. M.; Lima, F. A.; Calado, V.; Marriott, P. J.; de Aquino Neto, F. R.; Rezende, C. M. Isolating Valuable Coffee Diterpenes by Using an Inexpensive Procedure. Ind. Crops Prod. 2020, 152, 112494. 